\title{
THE ACLEC REPORT — MEETING LEGAL EDUCATION NEEDS IN THE 21ST CENTURY?
}

\author{
RICHARD GRIMES*
}

\section{BACKGROUND}

The Lord Chancellor's Advisory Committee on Legal Education and Conduct (ACLEC) was established in 1991 with the remit of advising on the education and training of legal service providers. ${ }^{1}$ The Committee has a statutory duty to consider the relevancy of legal education to the needs of both practitioners and the members of the public. Their work is limited to legal education in England and Wales but, I suggest, is of relevance to jurisdictions elsewhere in the common-law world, especially in view of contemporary discussions, on the international scene, on the form and content of legal education. ${ }^{2}$

The last significant and comprehensive review of legal education in Britain was in $1971 .^{3}$ The Ormrod Report of that year identified three distinct levels of development: the academic; the vocational; and continuing or post qualification legal education. As has been noted elsewhere, the distinction between these stages of the educational process has dominated both the philosophy and delivery of legal education for more than 25 years. $^{4}$

The ACLEC committee undertook, shortly after its appointment in 1991, a review of all aspects of legal education, and through consultative papers ${ }^{5}$ and conferences: canvassed views from a wide range of interested parties including educational providers, government law officers, the judiciary and private legal practice. Academic research studies, both existing and commissioned, together with expert consultants, were used to supplement the consultative process. This led to the publication in April 1996 of ACLEC's First Report on Legal Education and Training. ${ }^{7}$ A consultative conference on the Report was held in July 1996. ${ }^{8}$ A further report that deals specifically with the continuing professional development of barristers and solicitors is expected in April 1997. A consultative paper on the education and training of para-legals is to be issued at the same time.

\section{SO WHAT DOES THE REPORT SAY AND WHAT ARE THE IMPLICATIONS OF ITS RECOMMENDATIONS?}

\section{The First Report}

The report locates the review of legal education firmly in the context of current and future needs from the perspective of legal service providers, educators and consumers.

It recognises that market forces have impacted significantly on legal education since the Ormrod days. Reference is made to a "legal services revolution" and to the restructuring and increased complexity of legal service provision both in the private and public sectors.

The Report also identifies the major changes that have taken place in higher or tertiary education. The growth of university and college student populations, ${ }^{10}$ the diversification of programmes and choices, and the pressure brought about by the reduction in the public funding of education are all specifically noted. ${ }^{11}$ Added to this, universities and colleges have, over the last 10 years, played an increasingly important role in the provision of vocational and postgraduate legal education.

The need and demand for intellectual and professional skills is highlighted ${ }^{12}$ as is the requirement for a 
strong and clear ethical component. ${ }^{13}$ There is an increasing tendency for law students not to follow a vocational career but to follow a variety of (often) non-law specific work related options. ${ }^{14}$ This latter point, in part, leads ACLEC to call for "multiple entry and exit points” into, and out of, the legal education structure. ${ }^{15}$

The Report prefaces its detailed examination and its recommendations by making raising two significant points (identified in the report as "serious structural weaknesses" in the existing system of legal education in England and Wales). These are:

- "the artificially rigid" separation of the stages of legal education (academic and professional)

- the commonly perceived role of the law degree as largely a preparatory step to entry to vocational training $^{16}$

The observation is also made, later in the Report, that the quality of legal education provision would be generally enhanced if universities and colleges were given greater autonomy and consequently more freedom to decide on the curriculum and the means by which it can be delivered. ${ }^{17}$

\section{Access and Funding}

In a closely referenced and statistically supported section, headed Access and Funding, the Report addresses equality of educational and career opportunity, and concludes that despite increasing numbers studying law, no arbitrary restrictions should be placed on entry to the profession and that law schools should review their own admission and training procedures to support equality of opportunity ${ }^{18}$ On the funding of legal education, the Report suggests that greater support is needed for students in the form of "an equitable distribution of costs between the individual student, the employer, the profession as a whole, and the public". 19

\section{Universities and Colleges}

The Report goes on to consider the role of university education and identifies the desirability of intellectual rigour, core and contextual knowledge, legal values and ethical standards, and analytical, conceptual and communication skills, in degree programmes. ${ }^{20}$ The importance of a route for non-law graduates is stated with the value of a conversion course accepted. ${ }^{21}$ In a rather broad and undefined statement, the Report calls for the adoption of active learning methods and a move away from rote learning towards greater flexibility and diversity of teaching and assessment methods. ${ }^{22}$ There is a strong commitment in the report to the independence of the educational provider within defined boundaries. ${ }^{23}$

\section{Legal Practice Courses}

The vocational courses currently offered in England and Wales, that lead respectively to the qualifications of solicitor and barrister, are supported as building up the required level of lawyering skills for a would-be practitioner. ${ }^{24}$ The importance of practical work-based legal experience is emphasised through a form of apprenticeship is stressed, albeit shortened from the current requirements of two years for an intending solicitor and one year for a barrister. Where possible there should be "interchange between students and ... the evolution of common areas of training”. 25

\section{Quality Control}

The Report also raises, what for some is, the spectre of quality control. Constructively used, this is essential to monitor and support provision in education, whether legal or otherwise. Minimum standards for human and physical resources and effective policies for admission, teaching, and assessment are all seen as pre-requisites to the provision of good legal education. ${ }^{26}$

\section{Continuing Legal Education}

The Committee considers the question of the need for continuing legal education, or as they term it, "professional development”. Whilst recognising the vitally important role this has to play in the process of "life-long learning”, the substance of the Committee's views will be contained in the report on this stage, 
due to be released in April 1997.

So far so good one might say. The Report largely accepts the need for an educational continuum, in which universities and colleges play the principal role in serving educational need, by providing a liberal educational experience that relates closely to career development beyond graduation, and that nourishes intellectual and practical knowledge, understanding and skills. This educational framework should be fairly and adequately resourced.

But what else does the Report say that may mitigate against the commendable, if somewhat sweeping, statements in the preceding paragraph?

\section{THE PROBLEMS}

The ACLEC committee talks generally of its preference for non-prescriptive curricula where universities, within the context of quality control, resourcing constraints and the broad aims of undergraduate legal education, should be encouraged to design and implement law teaching according to their own stated objectives. ${ }^{27}$ The Committee however then proceeds to lay down expectations that prescribe minimum content (to be a "qualifying degree" the programme must consist of at least two thirds "legal subjects" 28 ). The Report goes further and includes what it terms as "an illustrative statement of outcomes" ${ }^{29}$ Although it is admittedly a tough challenge, the Committee does not really come to terms with definitions and there is little serious attempt to explore the meaning of "legal subjects" and whether those institutions who do provide instruction in, say, such core units as Land Law or Torts, do actually meet the wider expectations contained in the early parts of the Report.

\section{Learning and Teaching}

Teaching and learning methodology is given scant attention. Although innovative and student centred learning activities are fleetingly supported, no meaning is given to the discussion in the sense of how educational theory would back up this call, and how far this would complement the overall need for improvements in the quality of legal education. The Report is careful to avoid overt criticisms or even mention of particular pedagogic models, preferring to encourage flexibility of approach. In a Report that attempts to go to the heart of legal education, it is a great pity that a mere two paragraphs are given to teaching methods and assessment in the context of the law degree. An opportunity is clearly missed here to examine alternative but complementary ways of learning, in particular experiential or clinical legal education. $^{30}$

\section{Law Staff}

And what of the law teachers themselves? As Leighton notes, this is virtually ignored by the report other than implicit recognition that if law programmes are to cover the liberal base recommended and incorporate core and contextual knowledge and active learning, whilst encouraging research and scholarly activity, some investment in the teachers themselves is necessary, both in terms of appointment and staff development. ${ }^{31}$

\section{The Licentiate Stage}

There is more. One of the central themes of the Report is the need for common professional legal studies. ${ }^{32}$ The desirability of giving multiple points of entry and exit and (to some extent) the shared interests of intending barristers, solicitors and para-legals, leads the Committee to the conclusion that a common stage of vocational or professional education is needed. This is seen as best provided as additional to, rather than instead of, existing components in the professional practice obstacle course. The Report recommends that a new qualification called the Licentiate in Professional Legal Studies be introduced. This would follow the law degree/conversion course stage and would fall between that and the vocational course proper for barristers or solicitors. The commonality here makes some sense in that it would provide joint education and training for would-be practitioners before their intended route of specialism were followed. In view of the focus of the course leading to this qualification, the length of the dedicated vocational 
courses for barristers and solicitors respectively would be reduced, as would the apprenticeship stage that follows.

The logic of this set of recommendations, although perhaps introduced for the right reasons (making the most of the common needs of the two parts of the practising profession), is difficult to follow in its application. Presuming that England and Wales continues to have a split profession (and there would seem to be substantial resistance, particularly from the Bar, to any attempt to share education let alone fuse the profession), either there is a need for the separate vocational education of the two sides or there is not. If there is the need, can this not be addressed either at the apprenticeship stage or as the position presently is, in a dedicated practice course? There is considerable merit in the shared aspect of vocational education both from the point of reinforcing the educational continuum and in maximising resources. If the potential of universities and colleges is to be utilised, the common, overtly vocational, elements of legal education can be built on the expanding skills base of the degree programme by extending the degree for those who wish to stay on to cover professional practice requirements, and then, allowing students to effectively take the barristers' or solicitors' option. There would, in this model, be a shared first part and a specialised second part of the course. So far as it matters the shared first part could offer a qualification for those not wishing to carry on to the second phase, although it has been doubted elsewhere whether such a qualification would be of use for non-barristers or solicitors in any event. ${ }^{33}$

If the intention of the Report is to promote the legal education continuum and the service of professional needs, how can this be done unless there is a substantial extent of integration between the present stages of legal education? The introduction of another hurdle and stage in itself is unlikely to assist, and may do no more than to frustrate the aspirant lawyer, rather than to provide meaningful points of entry and exit.

\section{The Apprenticeship}

One further aspect of the Report must be examined - the lawyers' apprenticeship. The report deals with this, recognising that work based, in-service training is essential to the education of both barristers and solicitors. ${ }^{34}$ In view of the introduction of the Licentiate stage and the retention of the dedicated vocational courses for barristers and solicitors, the Report suggests that the period of apprenticeship (split into a "before" and "after" vocational course) be reduced. The Committee might have considered de Groot's study on Producing a Competent Lawyer and his conclusions that articles are more likely to produce uneven results in terms of lawyer competence when compared with a dedicated professional practice course. ${ }^{35}$ In a nutshell, the trainee's experience of apprenticeship can be hit and miss. A well structured and strategically planned programme is preferable. The combination of the Licentiate, specialised vocational, and apprenticeship stages would lead to a coherent and properly monitorable system. It would be less susceptible to the vagaries of the market place - ask any law student who cannot secure their pupillage or training contract. This should build on the degree curriculum and include a strong clinical or hands-on dimension. Although the law degree should not be dictated to by the demands of vocational education, siting both "stages" in the Law School would represent, in the clearest possible way, the continuum that the Committee calls for, and would ensure a maximisation of resources and a healthy interaction of lawyers at their different levels of development. A similar argument could also be made for continuing legal education but that is beyond the scope of this review.

\section{LESSONS TO BE LEARNT}

ACLEC has conducted a highly significant and far reaching review of legal education in England and Wales. Discussions that centre on skills and the legal academy, active and passive learning, how far law schools should serve professional needs, and in-house vocational training as compared with apprenticeships, are all pertinent issues that trouble many institutions and jurisdictions. It is easy to criticise the Report both for what it says and for what it omits. The task of the reform of legal education is a daunting one, none the least because the legal profession, the law faculty and the government exchequer have a long history of resistance to change and demands on the purse.

The last 10 years or so have seen many developments that make the movement towards achieving an overhaul of legal education — to make it more productive and student and (eventually) client sensitive - 
more sustainable. As law teachers we are more aware of educational theory and learning. As policy makers we are more conscious of the need for quality and better use of resources. As lawyers we are (slowly) coming to the realisation that we can educate ourselves as a whole rather than small pieces of each other. The cynic will say that little may change. He or she may be right. What is certain is that in Britain, there is an opportunity for a major realignment of legal education provision.

* Director and Associate Professor, Institute of Justice and Applied Legal Studies, University of the South Pacific, presently on secondment from Sheffield Hallam University, Sheffield, England, UK. (C)1997. (1996) 7 Legal Educ Rev 281.

1 Courts and Legal Services Act 1990 (UK), sch 1, para 1.

2 For example see: D Pearce et al, Assessment for the Commonwealth Tertiary Education Commission (Canberra: AGPS, 1987) and R MacCrate et al, Legal Education and Professional Development - An Educational Continuum - Report of The Task Force on Law Schools and the Profession: Narrowing the Gap (Chicago: ABA, 1992).

3 Great Britain, Report of the Committee on Legal Education (Ormrod Report) (London: HMSO, 1971) Cmnd 4595. There have been subsequent reviews (Great Britain, Royal Commission on Legal Services (Benson Report) (London: HMSO, 1979) Cmnd 7648 and L Marre, Report of the Committee on the Future of Legal Profession - A Time for Change (Marre Committee) (London: General Council of the Bar and the Law Society, 1988)) but ACLEC represents the first attempt since Ormrod to critically examine all aspects of legal education and has invited and received widespread comment and discussion.

4 P Leighton, The First ACLEC Report: What might it mean for law teachers? (1996) 30 L Tchr 201.

5 ACLEC, The Initial Stage (London: ACLEC, June 1994); ACLECL, The Vocational Stage and Continuing Professional Development (London: ACLEC, June 1995); and, ACLEC, Continuing Professional Development (London: ACLEC, June 1996).

6 July 1993, July 1994 and July 1995.

7 ACLEC, First Report on Legal Education and Training (London: ACLEC, 1996).

8 For a summary of the conference see: ACLEC, First Report on Legal Education and Training - Report of the Proceedings of the Conference held a 8 July 1996 (London: ACLEC, 1996).

9 First Report on Legal Education and Training, supra note 7, at 11.

10 For a revealing, if alarming, set of statistics on the expansion of student numbers and the limited resources available to deal with them see: (1996) 94 Ass'n L Tchs Bull 1. From research conducted by P Hams, Law Teachers and Teaching Strategies after ACLEC, paper presented at the Association of Law Teachers Conference, 1 November 1996, (in (1996) 94 Ass'n L Tchs Bull 1, at $2-5$ ) there has been a $50 \%$ increase in law student numbers in universities and colleges in the UK, with a $3 \%$ growth of staff over the same period.

11 Id at 21-22.

12 Id at $14-16,56-57$.

13 Id at $17-18$.

14 Leighton, supra note 4, at 201, suggests that this may be as high as $70 \%$. This figure is probably an over-estimate but approximately one half of all law graduates are currently not entering the legal profession (see Association of Law Teachers, Bulletin, supra note 10, at 12) and it is clear that this tendency is increasing.

15 The First Report on Legal Education and Training, supra note 7, at 22,31-33.

16 Id at 27.

17 Id at 58.

18 Id at 45.

19 Id at 49

20 Id at 68

21 Id at 69-71.

22 Id at 61-65.

23 Id at 64.

24 Id at 90.

25 Id at 91.

26 Id at 99-105.

27 Id at 64

28 Id at 67.

29 Id at 72.

30 A submission on behalf of the Clinical Legal Education Organisation (UK) was made to the Committee and this is acknowledged in the Report (Id at 124). The Committee also notes the American Bar Association's prescription for an opportunity for students to opt for clinical classes (Id at 62).

31 Leighton, supra note 4, 206-207.

32 The First Report on Legal Education and Training, supra note 7, at 73.

33 See A Sherr, Vocational Education and Training - a Critique, in First Report on Legal Education and Training — Report of the Proceedings of the Conference, supra note 7, at 41.

34 First Report on Legal Education and Training, id, 91-97.

35 J de Groot, Producing a Competent Lawyer — Alternatives Available (Centre for Legal Education: Sydney, 1995) 189-191. 